\title{
Cultural Implications of a Study of Police Communication With Minorities
}

\author{
Halil Asllani \\ Kosovo Academy for Public Safety \\ John R. Fisher \\ Utah Valley University
}

Recent protests and riots around the globe have renewed the call for police reform. While police reforms could benefit the police and the public, police training in cultural awareness, racial biases, and communications may result in better and faster changes in police attitudes and approaches for working with minorities. This study suggests that non-police public safety personnel perceive a greater need for police training than the police. The study examined the police relationship and their communication with minority populations as perceived by Kosovo police $(N=20)$ and other public safety personnel $(N=24)$. Respondents answered a quantitative survey. Although not statistically significant, it appears that most police respondents didn't recognize that cultural barriers exist between minorities and police, and they didn't feel a strong need for cultural training. On the other hand, other public safety personnel showed greater support for cultural training, recognizing that cultural barriers do exist between police and minorities. Both groups agreed that trust is more important than speaking the same language when working with minorities.

Keywords: communications, cultural awareness training, language acquisition, minority relations, police reform, Kosovo, trust

\section{INTRODUCTION}

The police reform movement has ignored the fact that much of what police do could be labeled social work. Traditionally, the police enforced the law, leaving people problems to social workers. Yet, today police officers seem to be more and more involved in helping people cope with the difficulties and challenges of life. According to a Tulane University (2019) blog, "The discipline of social service has become a necessary aspect of community policing, as police officers do much more than enforce laws and fight crime. They assist in maintaining the welfare of citizens by monitoring community health and safety issues and intervening on a social level."

Getting police involved in social service work has been difficult because of the traditional view of the police role in law enforcement and crime prevention. While most police training centers on fighting crime, criminal law, personal defense and use of weapons, much of the daily activities of police officers is related to social services. They spend much of their time resolving conflicts, dealing with family disputes, and delivering other services to community members. 
These functions require effective communications and relationship building skills. Tulane University suggests that these and other social work skills be taught in police academies and other training sessions. In addition to communications, police need to know mediation and conflict resolution skills. Police also need to be able to recognize signs of mental illness and drug addiction and know how to respond appropriately to people with these and other diseases.

Thus, the connection between police and community becomes a primary aspect of policing. This study examines police relationship and communication with minority populations as perceived by Kosovo police and other public safety personnel. Training needs for police are derived from results of the study.

\section{BACKGROUND}

The discussion of police reform in the United States increased following protests after the shooting of Michael Brown in Ferguson, Missouri, in 2014. However, no progress on police reform was made until 2020, when protests and riots followed the deaths of black citizens in Minneapolis and Atlanta. Most suggestions for reforms have to do with the way policing is done, not with training. Capps (2016) claimed, "Law-enforcement agencies are simply resistant to instruction that would help local law enforcement police better." Sarano (2016) warned: "There's no way that racial bias training alone can get rid of racial discrimination in policing, but the only way to work against implicit bias is to raise awareness about it." Sarano wrote that police chiefs should lead the way by offering this training to their officers.

In response to the public outcry about police tactics, The White House required certification bodies to assure training of officers on de-escalation technique and use of force standards. The U.S. federal government was to provide incentives to improve law enforcement practices and build community engagement. Use-of-force policies would prohibit the use of chokeholds. Co-responder programs would be created, which would involve social workers and mental health professionals working alongside law enforcement officers. Police officers would be trained to work with individual suffering from impaired mental health, homelessness and addiction (The White House, 2020).

Fisher and Asllani (2019) studied police and other public service communication in the state of Utah in the United States. According to the authors, cultural sensitivity is best achieved through understanding the history and background of the minority people and interacting with them. Public servants resist and soon forget classroom sessions in diversity and "sensitivity" training. Further on, Fisher and Asllani postulated: "The greater people's experience and interaction with minority populations the better they are able to serve and work with understanding and empathy in the public services."

Manoj and Baker (2007) describe the sociological challenges faced by police. "Sharing and dissemination of information is both critical and problematic, beginning with whom to trust in unfamiliar settings. Even after a level of trust is established, security issues must still be considered. Another important factor is the emotional volatility of the victim population. Fear, stress, and other emotions are aggravated by the lack of information" (p. 51).

According to Hennessy, Hendricks, and Hendricks (n.d.), law enforcement educators and researchers divide cultural awareness training for the police into two types: race-relations training and cultural awareness models of training. Race relations models focus on increasing awareness of personal attitudes towards race and understanding of the structural dynamics of racism. Cultural awareness models or intercultural training emphasizes cross cultural understanding and self-awareness.

Race-relations based courses seem to be less effective than cultural awareness models. They include exercises that can be "demeaning to participants as well as having little real-life value." Cultural awareness models are thought to be more effective because they stress the changing demographics of communities and the changes in the policing profession. The courses are job- related, placing of the job in the context of policing (pp. 9-10).

In regard to the reasons for police officer failure to communicate, Glennon (2012) claims that most of the time, when police anger the public, they do it unintentionally. The officers often are unaware of delivery and audience. Officers lack technical skills in communications and sometimes they just don't care. Police officers often unintentionally escalate hostilities, even in routine situations. 
Police learn to protect themselves and this spills over into communications. Glennon writes, "Cops are pretty good at ... establishing a command presence, and/ or communicating alternatives and consequences in order to discourage physical assaults." While this is an important skill to have, the attitude of command can cause poor communication, especially among minority groups, where it actually prevents rapport building (p. 19).

In a study conducted about police and minority relations in the Balkan states, Konstantinov (1992) surveyed the close interaction between the nation-state institutions and the Bulgarian minority communities, namely the mass media, national holidays, educational bodies, army and police. The paper argued that a careful and critical appraisal of existing attitudes with respect to these societal areas is necessary if ethnic conflicts of post-totalitarian changes were to be avoided.

Konstantinov investigated ethnic problems in post-totalitarian Bulgaria by examining two types of discourse - 'nation-state discourse' and 'minority discourse'. Nation-state discourse practiced by the Bulgarian majority centered around language, history, tradition, and religion and defended the existence and sustainability of the nation-state. The nation-state culture was centered on 'visible' codes, like language, that provided proof of the homogeneity and historical origin of the nation-state. In contrast, minority discourse, used by the Islamic populations of Turks, Pomaks, Turkish Gypsies, revolved around issues of integration and accommodation of either a demographic and/or economic character. The minorities were concerned with 'ethno-methodologies' of survival, especially during the very critical post-totalitarian period. Konstantinov concluded: "Balkan ethnic conflicts between majority and minority communities stem to a significant extent from a feeling of insecurity the nation-states themselves experience. In this sense, a long-term solution requires a much wider effort for bringing a sense of stability and security to this muchtroubled part of Europe" (pp. 75-89).

\section{Policing and Minorities in Kosovo}

Kosovo and the neighboring region have been plagued by racial conflict for centuries. While Kosovo was a province in Serbia, it was controlled by Serbian administrators and Serbian police. Now that Kosovo is a country, the mainly Albanian Kosovo police force is charged with policing the Serb minority. Kosovo's war in 1998-1999 created demographic and political changes that continue to impact the nation and region negatively. Prior to the conflict, 1.6 million people lived in Kosovo, with 90 percent ethnic Albanians and six percent Serbs. During the war, Serbian attempts at "ethnic cleansing" resulted in about 800,000 ethnic Albanian refugees fleeing to neighboring countries of Macedonia, Albania, and Montenegro, while another 500,000 were displaced internally. About a third of the buildings and heritage sites in the country were destroyed. While most of the Albanian population returned to Kosovo, about 100,000 ethnic-Serbs, who feared reprisal, fled north to Serbia (Greene, Friedman, \& Bennett, 2012).

In 2019, the total population was over 1.9 million. Estimates from the 2011 census divided the population among Albanians $92.9 \%$, Bosniaks $1.6 \%$, Serbs $1.5 \%$, Turk 1.1\%, Ashkali $0.9 \%$, Egyptian $0.7 \%$, Gorani $0.6 \%$, Romani $0.5 \%$, other/unspecified $0.2 \%$. These percentages may be low for ethnic-Serbians and Romanis because many Serb and Romani communities refused to participate in the census (Central Intelligence Agency, 2019).

Since declaring independence in 2008, Kosovo has been recognized by over 100 countries, including the United States, Canada, Britain, France, Germany, and Italy. Russia, China and five European Union nations - Spain, Greece, Bulgaria, Romania, Slovakia, and Cypress - are among the countries that have sided with Serbia, by not recognizing Kosovo's independence. Serbia still considers Kosovo as one its provinces, even though it has no authority in Kosovo. The impasse has kept the conflict festering and prevented stabilization of the region (Vallely, 2008). Many Kosovar Serbs continue to oppose Kosovo government regulation and look north to Serbia for direction. In 2018, Kosovo put a 100\% tariff on Serbian goods, because Serbian opposition resulted in a no vote to Kosovo membership in Interpol (Morina, 2019).

In 1999, under the direction of the United Nations and with the support of the U.S. Department of Justice and its International Criminal Investigative Training Assistance Program (ICITAP), OSCE began a training program for a new Kosovo police force (Greene, Friedman, \& Bennet, 2012). About 13,000 public safety personnel have been trained at the Kosovo Academy of Public Safety (KAPS) in Vushtrri. They 
serve in Kosovo Police (KP), Correctional Service (KCS), Kosovo Probation Service (KPS), Kosovo Customs (KC), the Agency of Emergency Management (AEM) and Kosovo Police Inspectorate (KPI) (Kosovo Academy of Public Safety, n.d.). About 90\% of the 9000 Kosovo police officers are ethnic Albanians while $10 \%$ are ethnic minorities with mostly Serbs.

\section{STUDY PURPOSE}

The purpose of this study is to see how police perceive their relationship and communication effectiveness with minorities. Other public safety personnel are also surveyed for their view of the police relationship and communication with minorities. Kosovo police are used as a case study. Relationship factors considered are age, communication, culture, language ability, and trust.

This study is quantitative where a survey using a Likert scale was used as the main data collection instrument. Results from the study were analyzed and recommendations were made for training to improve the communication and relationship aspects of policing minorities.

- The hypothesis for the study is: Police in Kosovo perceive their relationship with minority populations significantly differently than other public safety personnel view the relationship.

- The null hypothesis states: No significant difference exists between the police and other public safety personnel in their perception of police relationship with minorities.

\section{METHODOLOGY}

This study piloted 23 Likert-style statements in English to which respondents indicated strong agreement, agreement, neutrality, disagreement, and strong disagreement. The survey was administered to a class of 44 English language students at a public safety academy in Kosovo. Because students had varying levels of English-language proficiency, the class instructor and researcher were available to answer any unclear questions.

The first independent variable considered in the analysis was Age. Table 1 shows that Age was grouped into four categories: 20-29, 30-39, 40-49, 50 and over. For analysis, 20-39 were grouped together (numbering 20) and 40 and over were grouped together (numbering 21).

TABLE 1

AGE GROUPED

\begin{tabular}{|c|c|c|c|c|c|}
\hline \multicolumn{2}{|c|}{} & Frequency & Percent & Valid Percent & Cumulative Percent \\
\hline \multirow{3}{*}{ Valid } & $20-29$ & 9 & 20.5 & 22.0 & 22.0 \\
\cline { 2 - 6 } & $30-39$ & 11 & 25.0 & 26.8 & 48.8 \\
\cline { 2 - 6 } & $40-49$ & 19 & 43.2 & 46.3 & 95.1 \\
\cline { 2 - 6 } & 50 plus & 2 & 4.5 & 4.9 & 100.0 \\
\cline { 2 - 6 } & Total & 41 & 93.2 & 100.0 & \\
\hline \multicolumn{2}{|c|}{ Missing } & 3 & 6.8 & & \\
\hline \multicolumn{2}{|c|}{ Total } & 44 & 100.0 & & \\
\hline
\end{tabular}

Table 2 breaks down the respondents by Agency. The number of "Police" responding was 20. The remaining 24 respondents were grouped in one category called "Other," since so few representatives came from emergency management, the academy, and border guards. The "Other" group included 17 corrections officers, 3 emergency management students, 1 academy employee, and 3 border guards. 
TABLE 2

AGENCY

\begin{tabular}{|l|l|c|c|c|c|}
\hline \multicolumn{2}{|c|}{} & Frequency & Percent & Valid Percent & Cumulative Percent \\
\hline \multirow{3}{*}{ Valid } & Police & 20 & 45.5 & 45.5 & 45.5 \\
\cline { 2 - 6 } & Corrections & 17 & 38.6 & 38.6 & 84.1 \\
\cline { 2 - 6 } & $\begin{array}{l}\text { Emergency } \\
\text { Management }\end{array}$ & 3 & 6.8 & 6.8 & 90.9 \\
\cline { 2 - 6 } & Academy & 1 & 2.3 & 2.3 & 93.2 \\
\cline { 2 - 6 } & Border Guards & 3 & 6.8 & 6.8 & 100.0 \\
\hline & Total & 44 & 100.0 & 100.0 & \\
\hline
\end{tabular}

The other categories of gender, education, and nationality were not analyzed, because of low numbers in sub-groups. There were 40 men and only 4 women; 34 had graduated from high school and only 7 from university; 36 indicated their nationality was Albanian and only two declared themselves as Serbian.

SPSS software was used for statistical analysis. Survey results were analyzed using the Mann-Whitney $\mathrm{U}$ test, a non-parametric tool, with independent variables being Agency and Age groups. The statements were used as the dependent variables. The Mann-Whitney $U$ test established statistical significance (p values), which would allow the researchers to reject the null hypotheses. Crosstabs were used to show percentages and how responses differed proportionally. A Somers'd test for statistical significance verified the results from the Mann-Whitney $U$ test and showed directional measures for statements.

\section{RESULTS}

The Mann-Whitney U test of significance showed no significant differences in responses broken down by Age. The researchers were unable to reject the null hypothesis that "no significant difference exists between the police and other public safety personnel in their perception of police relationship with minorities."

On the other hand, the Mann-Whitney $U$ test showed significant difference $(p<.05)$ for two statements related to Agency. These results were verified by the Somers'd test for significant difference.

2. "Cultural barriers exist between police and minority populations in Kosovo" and

8. "Getting cultural awareness training is vital for the successful operation of my job."

For both statements the the null hypothesis, "no significant difference exists between the police and other public safety personnel in their perception of police relationship with minorities," was rejected.

For both statements, directional measures from the Somers'd test were negative, showing the directional measures leaned toward responses from "other" emergency services personnel. If asked to reply to Statement 2, 34.2 percent of "other" emergency service personnel would answer the same way. If asked to reply to Statement $8,38.8$ percent of "other" emergency service personnel would answer the same way. In Table 3, approximate significances are displayed. The significance level is .05. Directional measures for Statement 2 is -.342 and for Statement 8 is -.388 . 
TABLE 3

HYPOTHESIS TEST SUMMARY

\begin{tabular}{|l|c|c|c|}
\hline \multicolumn{1}{|c|}{ Null Hypothesis } & $\begin{array}{c}\text { Significance for } \\
\text { Mann-Whitney } \\
\text { U }\end{array}$ & $\begin{array}{c}\text { Significance for } \\
\text { Somers'd test }\end{array}$ & Decision \\
\hline $\begin{array}{l}\text { 2. The distribution of "Cultural barriers } \\
\text { exist between police and minority } \\
\text { populations in Kosovo" is the same across } \\
\text { categories of Agency. }\end{array}$ & .044 & .031 & $\begin{array}{l}\text { Reject the null } \\
\text { hypothesis. }\end{array}$ \\
\hline $\begin{array}{l}\text { 8. The distribution of "Getting cultural } \\
\text { awareness training is vital for the } \\
\text { successful operation of my job" is the } \\
\text { same across categories of Agency. }\end{array}$ & .018 & .008 & $\begin{array}{l}\text { Reject the null } \\
\text { hypothesis. }\end{array}$ \\
\hline
\end{tabular}

Table 4 lists the 23 statements from the Likert survey, highlighting crosstab results where percentages from Agree and Strongly Agree are added together to show one agreement percentage for Others and another for Police. Results for disagree and strongly disagree also are added together to show a "disagreed" percentage for Other respondents and Police.

TABLE 4

CROSSTAB PERCENTAGES OF AGREEMENT FOR OTHERS AND POLICE

\begin{tabular}{|c|c|c|c|c|}
\hline \multicolumn{1}{|c|}{ STATEMENTS } & $\begin{array}{c}\text { Other \% } \\
\text { Disagreed }\end{array}$ & $\begin{array}{c}\text { Police \% } \\
\text { Disagreed }\end{array}$ & $\begin{array}{c}\text { Other } \\
\text { \%o } \\
\text { Agreed }\end{array}$ & $\begin{array}{c}\text { Police } \\
\text { \%greed } \\
\text { Agreed }\end{array}$ \\
\hline 1. $\begin{array}{l}\text { Language barriers exist between police and } \\
\text { minority populations in Kosovo. }\end{array}$ & $20.5 \%$ & $15.9 \%$ & $34 \%$ & $20.5 \%$ \\
\hline $2 . \quad \begin{array}{l}\text { Cultural barriers exist between police and } \\
\text { minority populations in Kosovo. }\end{array}$ & $15.9 \%$ & $29.5 \%$ & $25 \%$ & $13.6 \%$ \\
\hline 3. $\begin{array}{l}\text { Younger police and minority members use } \\
\text { English to overcome language barriers. }\end{array}$ & $0 \%$ & $6.8 \%$ & $47.7 \%$ & $29.5 \%$ \\
\hline 4. I have experienced cultural differences when \\
communicating in my job.
\end{tabular}




\begin{tabular}{|c|c|c|c|c|}
\hline $\begin{array}{l}\text { 11. The generation gap causes communication } \\
\text { barriers between police and minority } \\
\text { populations. }\end{array}$ & $11.4 \%$ & $6.8 \%$ & $13.7 \%$ & $11.4 \%$ \\
\hline $\begin{array}{l}\text { 12. It is harder for younger people to communicate } \\
\text { with older police officers. }\end{array}$ & $25 \%$ & $25 \%$ & $13.7 \%$ & $4.5 \%$ \\
\hline $\begin{array}{l}\text { 13. Younger people have fewer biases in } \\
\text { communicating with people of other } \\
\text { backgrounds. }\end{array}$ & $4.5 \%$ & $2.3 \%$ & $43.2 \%$ & $27.2 \%$ \\
\hline $\begin{array}{l}\text { 14. When communication with minorities is not } \\
\text { possible, I use English. }\end{array}$ & $4.5 \%$ & $2.3 \%$ & $45.4 \%$ & $38.7 \%$ \\
\hline $\begin{array}{l}\text { 15. It is important that police have compassion and } \\
\text { empathy when communicating with minority } \\
\text { populations. }\end{array}$ & $6.8 \%$ & $6.8 \%$ & $43.2 \%$ & $25 \%$ \\
\hline $\begin{array}{l}\text { 16. It is important for police to have patience when } \\
\text { dealing with minority populations. }\end{array}$ & $4.5 \%$ & $6.8 \%$ & $40.9 \%$ & $34.1 \%$ \\
\hline $\begin{array}{l}\text { 17. Police must develop trust when working with } \\
\text { minority populations. }\end{array}$ & $2.3 \%$ & $2.3 \%$ & $50 \%$ & $38.7 \%$ \\
\hline $\begin{array}{l}\text { 18. Trust is more important than speaking the same } \\
\text { language when dealing with minority } \\
\text { populations. }\end{array}$ & $2.3 \%$ & $0 \%$ & $45.4 \%$ & $38.6 \%$ \\
\hline $\begin{array}{l}\text { 19. Police can build trust with minority } \\
\text { communities by working with community } \\
\text { leaders. }\end{array}$ & $2.3 \%$ & $6.8 \%$ & $45.5 \%$ & $31.8 \%$ \\
\hline $\begin{array}{l}\text { 20. Police can build relationships with minorities by } \\
\text { getting involved in community activities. }\end{array}$ & $2.3 \%$ & $2.3 \%$ & $40.9 \%$ & $36.4 \%$ \\
\hline $\begin{array}{l}\text { 21. Cultural awareness is best taught to police } \\
\text { officers by representatives of minority } \\
\text { populations. }\end{array}$ & $2.3 \%$ & $4.5 \%$ & $45.4 \%$ & $29.6 \%$ \\
\hline $\begin{array}{l}\text { 22. Police should provide education programs to } \\
\text { immigrants so they can understand the purpose } \\
\text { and role of police services. }\end{array}$ & $0 \%$ & $4.5 \%$ & $45.5 \%$ & $29.6 \%$ \\
\hline $\begin{array}{l}\text { 23. Police need resources, including translation } \\
\text { services, to assist minorities in emergency } \\
\text { situations. }\end{array}$ & $0 \%$ & $2.3 \%$ & $46.5 \%$ & $30.2 \%$ \\
\hline
\end{tabular}

These percentages are best illustrated by Figure 1, a chart which compares the combined percentages of agree and strongly agree and disagree and strongly disagree as side-by-side graphs. 


\section{FIGURE 1}

\section{PERCENTAGE AGREED, DISAGREED}

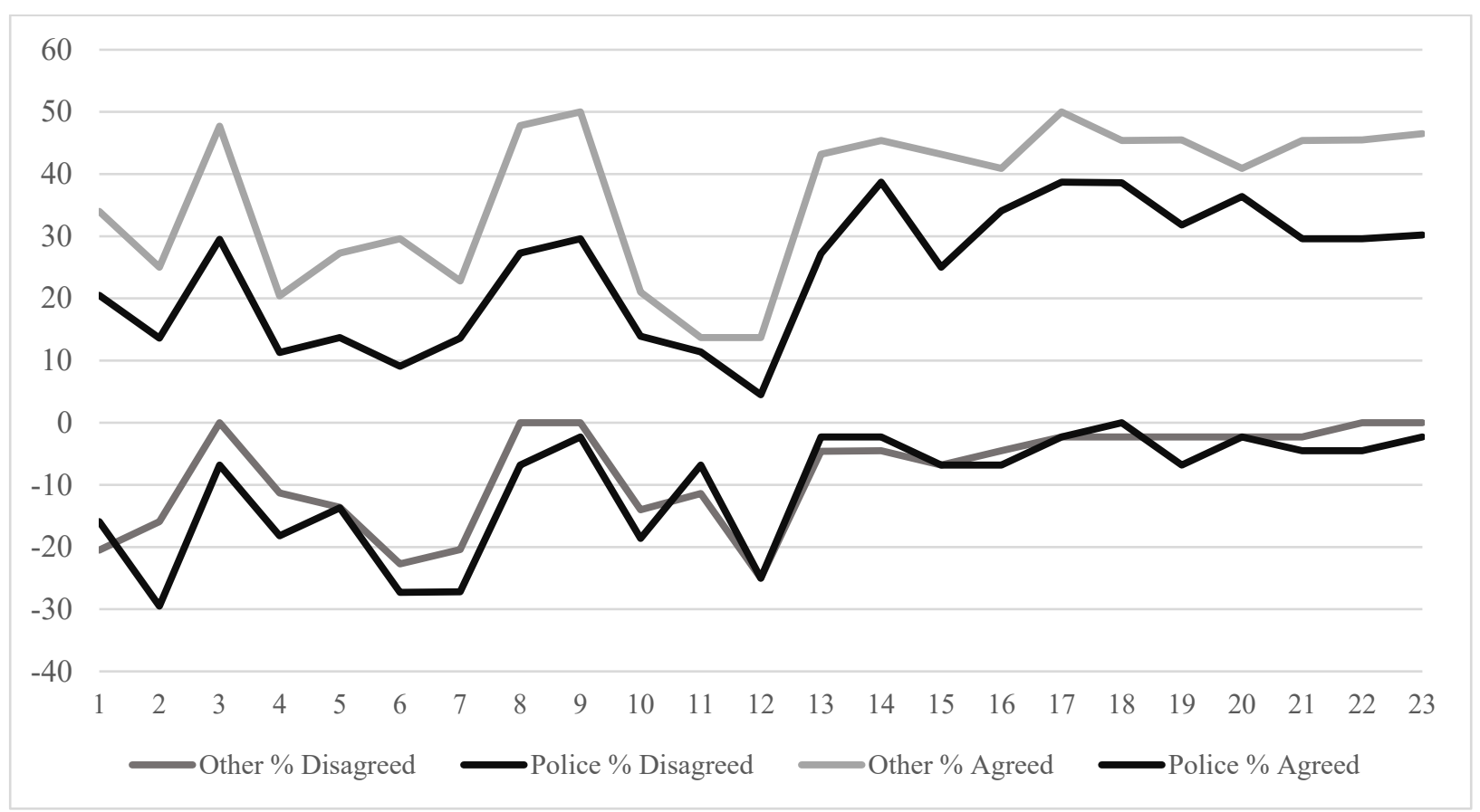

While Table 4 and Figure 1 do not provide statistically reliable data, they do provide valuable observational information. Based on observation, "other" respondents agreed more to all statements. Disagreement is shown as negative numbers to distinguish them on the chart from lines of agreement. The lines for disagreement for both groups of respondents appear to be very close.

The differences from Statements 2 and 8 are statistically significant using both the Mann-Whitney U and Somers'd tests. Directional measures from Somers'd show the data for these two statements skews toward "other" respondents. Differences in responses for all other statements are not significantly different.

Somers'd showed directional measures for all statements. All directional measures showed negative values pointing toward "other" respondents, except Statements 11, 16, and 18 which had positive values. While the differences were not statistically significant, the directional measures do suggest "police" respondents felt more strongly in the areas of generation gap, patience, and trust. The directional measure percentages were very small $-4.6 \%$ for statement $11,0.4 \%$ for statement 16 , and $6.0 \%$ for statement 18 .

\section{DISCUSSION}

Statistical significance is the most reliable means of showing differences between two groups. So what does it mean that police and other public safety respondents were significantly different for statements 2 and 8? The differences in responses for these two statements were great enough to be statistically significant. Police do not agree as strongly as other emergency personnel that cultural barriers exist (13.6\% versus $25 \%$ ) nor that cultural training is necessary (27.3\% versus $47.8 \%)$.

For both statements, the amount of difference between police who disagreed and agreed was also significant. Police disagreed more than they agreed. For statement 2, more police disagreed $(29.5 \%)$ than agreed (13.6\%). Similarly, for statement 8, more police disagreed $(27.2 \%)$ than agreed $(13.6 \%)$. For statement $2,15.9 \%$ of others disagreed versus $25 \%$ of others agreed. For statement $8,0 \%$ of others disagreed versus 47.8 of others who agreed. (See Table 5 below). 
TABLE 5

RESPONSE DIFFERENCES FOR STATEMENTS 2 AND 8

\begin{tabular}{|l|c|c|c|c|}
\hline \multicolumn{1}{|c|}{ STATEMENTS } & $\begin{array}{c}\text { Other \% } \\
\text { Disagreed }\end{array}$ & $\begin{array}{c}\text { Police \% } \\
\text { Disagreed }\end{array}$ & Other \% Agreed & Police \% Agreed \\
\hline $\begin{array}{l}\text { 2. Cultural barriers exist between } \\
\text { police and minority populations in } \\
\text { Kosovo. }\end{array}$ & $15.9 \%$ & $29.5 \%$ & $25 \%$ & $13.6 \%$ \\
\hline $\begin{array}{l}\text { 8. Getting cultural awareness } \\
\text { training is vital for the successful } \\
\text { operation of my job. }\end{array}$ & $0 \%$ & $6.8 \%$ & $47.8 \%$ & $27.3 \%$ \\
\hline
\end{tabular}

While the differences between police and other public safety personnel on other statements were not statistically significant, it is still worthwhile exploring the differences that do exist. The results show that police tend to disagree that a cultural barrier exists but support cultural awareness training. They generally support better communications and the importance of trust. They support greater involvement in minority communities and see the need for education of new immigrants and more resources for training and translation services.

There was weak support from both groups for statements $2,4,5,6,7,10,11$, and 12 . On each statement (except for 11), the police respondents disagreed more than they agreed. This suggests that police do not think cultural barriers are a problem between Kosovo police and minorities. While both groups agreed that language barriers exist between police and minorities (1), the agreement appears to be only slight (15.9\% of police disagreed versus $20.5 \%$ agreed). For statement 2, police didn't feel that "cultural barriers exist between police and minority populations in Kosovo," while other public safety respondents felt cultural barriers did exist. As stated before, the difference here was statistically significant.

Police didn't feel they had experienced cultural differences when communicating in their jobs (4). They were neutral on their opinion about having had to deal with situations because of cultural or religious differences (5). (Disagreement and agreement for police were both 13.7\%.) On statement 6, Police indicated that they didn't feel they had communication difficulties with minorities because of cultural differences. (27.3\% disagreed with the statement; $9.1 \%$ agreed.)

While the percentages varied greatly, both groups agreed on the issue of the lack of cultural awareness training and its need. While police admitted they didn't have training in cultural awareness (7), they agreed that getting cultural awareness training was vital for success in their jobs (8). (Statistical difference was significant for statement 8.) Both groups agreed that "cultural awareness training is very important to communication between police and minority populations" (9).

Both others and police generally showed strong support for statements about communications between minorities and young people and police: (1) language barriers exist, (3) young police use English to overcome language barriers, (9) cultural awareness is important to communication, (13) young people have fewer biases toward older police, and (14) police use English when communicating with minorities. They also agreed that (15) it is important that police have compassion and empathy when communicating with minority populations and (16) it is important to have patience when dealing with minorities. Police disagreed that it's "harder for the older minority population to communicate with police because of past experiences" (10). They were neutral about whether "the generation gap causes communication barriers between police and minority" (11). Finally, both groups disagreed that it's harder for younger people to communicate with older police officers (12).

Developing trust (17) was equally important for both groups. Trust is more important than language ability (18) and police should work with community leaders to build trust (19). Police should get involved in community activities (20) and learn culture from minority representatives (21). A need exists for education about policing for new immigrants (22) and for resources including translation services (23). 


\section{CONCLUSIONS}

This study examined the effectiveness of Kosovo police communication and relationship with minorities. While the police respondents didn't appear to recognize that cultural barriers existed, they agreed about the need for cultural training. They support the notion that building trust with minority populations is important and that this could be achieved by more effective communications and involvement in minority community activities. This information is important considering the demand for police reform and provides recommendations that could be applied in the other countries including Western Europe and North America.

Other emergency service personnel showed greater support for cultural training, recognizing that cultural barriers do exist between police and minorities. Both police and other emergency personnel agreed that they had not received cultural training. Both groups agreed that trust is more important than speaking the same language when dealing with minorities. Trust can be developed by working with minority leaders, being involved in community activities, and getting cultural training from minority community members. A need exists for education about policing for new immigrants and for funding for cultural and language training and translation services.

Because language barriers exist between police and minority populations, more language training is recommended. The study indicates that young police use English when language barriers exist. English language training is offered at the police academy in Kosovo, but while Serbian is an official language in Kosovo, it is not offered at the police academy. Most young people, who were raised after the Kosovo war, don't speak the Serbian language. The majority of police recruits are Albanian-speaking and should get training in the Serbian language. Ethnic-Serbian police candidates can get language accommodations at the police academy, but no formal Albanian language training is offered. This puts them at a disadvantage because most courses are taught in Albanian.

Some statements in the survey were directed specifically toward police while others were more vague. Other emergency personnel may have had difficulty distinguishing between whether statements were directed toward them or police specifically. Further study is needed with police specifically, particularly with police who deal with areas of high concentrations of minority people. Policymakers, administrators, and scholars would also benefit from studies of minority populations and their attitudes about police and policing.

Further studies should examine whether barriers do exist between police and minorities and the nature of these barriers. The following questions should be further explored: How can police improve their communication with minorities? Can police be trained to communicate more effectively with minorities? What kind of training is needed to improve police communication with minorities?

\section{REFERENCES}

Capps, K. (2014, December 4). 8 ways to get serious about police reform. Bloomberg CityLab. Retrieved from https://www.bloomberg.com/news/articles/2014-12-04/8-ways-to-get-serious-about-policereform

Central Intelligence Agency. (2019). The World Factbook - Kosovo. Retrieved from https://www.cia.gov/library/publications/the-world-factbook/geos/kv.html

Fisher, J.R., \& Asllani, H. (2019, April 4). Effective communication in public services in a diverse language and cultural landscape: A challenge in teaching and training. Unpublished paper presented at the 31st Annual Conference of the International Academy of Business Disciplines (IABD), Jacksonville, Florida, USA.

Glennon, J. (2012). Arresting Communication: Essential Interaction Skills for Law Enforcement. Villa Park, Illinois, USA.: LifeLine Training.

Greene, M., Friedman, J., \& Bennet, R. (2012, July 18). Case study Rebuilding the Police in Kosovo. Foreign Policy. Retrieved from https://foreignpolicy.com/2012/07/18/rebuilding-the-police-inkosovo/ 
Hennessy, S.M., Hendricks, J., \& Hendricks, C. (n.d.). Cultural Awareness Training for Police in the United States: A Look at Effective Methodologies. Minneapolis, Minnesota, USA. Retrieved from http://www.minneapolismn.gov/www/groups/public/@civilrights/documents/webcontent/wcms1 p-149102.pdf

Konstantinov, Y. (1992). Nation-State and Minority Types of Discourse - Problems of Communication between the Majority and the Islamic Minorities in Contemporary Bulgaria. Innovation in Social Sciences Research, 5(3), 75-89. https://doiorg.ezproxy.uvu.edu/10.1080/13511610.1992.9968310

Kosovo Academy of Public Safety. (n.d.). Background. Retrieved from http:/www.aksp-ks.net/?page=2,6

Manoj, B.S., \& Hubenko Baker, A. (2007). Communication Challenges in Emergency Response. Communications of the ACM, 50(3).

Morina, D. (2019, January 29). Kosovo sets conditions to drop tariffs on Serbian imports. Balkan Insight. Retrieved from https://balkaninsight.com/2019/01/29/kosovo-uses-tariffs-as-bait-for-a-finalagreement-with-serbia-01-29-2019/

Serrano, J. (2016, June 3). Five reforms every police department should make. Institute for Policy Studies. https://ips-dc.org/five-reforms-every-police-department-make/

The White House. (2020, June 16). Executive Order on Safe Policing for Safe Communities. Retrieved from https://www.whitehouse.gov/presidential-actions/executive-order-safe-policing-safecommunities/

Tulane School of Social Work. (2019, January 19). Why police officers are taking on social worker responsibilities. Retrieved from https://socialwork.tulane.edu/blog/why-police-officers-aretaking-on-social-worker-responsibilities

Vallely, P. (2008, February 19). The Big Question: Why are so many countries opposed to Kosovo gaining its independence? The Independent. Retrieved from https://www.independent.co.uk/news/world/europe/the-big-question-why-are-so-many-countriesopposed-to-kosovo-gaining-its-independence-783977.html 